Jurnal Care Vol .6, No.2,Tahun 2018

\title{
Analisis Pengetahuan Ibu Tentang Kenaikan Berat Badan Balita Usia 0-24 bulan \\ Dengan Kejadian Balita Gizi Kurang
}

Di Kota Kediri

\author{
Nurwijayanti ${ }^{1}$, Feby Lisanty Tobe ${ }^{2}$ \\ ${ }^{1}$ Dosen STIKes Surya Mitra Husada Kediri \\ ${ }^{2}$ Mahasiswa STIKes Surya Mitra Husada Kediri \\ e-mai: wijayantistikes@gmail.com
}

\begin{abstract}
Nutrition is wrong or not according to the needs will pose a problem of malnutrition in the form of excessive intake or reduced, while the factors that influence lack of nutrition in children is due to a lack of knowledge of the mother. The research objective for know relationship mother knowledge about the weight gain of children aged 0-24 mounth with the incidence of stunting Kediri District. The study design was corelational analitic with cross sectional approach. Respondents were taken by purposive sampling technique. The population of all mother toddlers aged 1-2 years in the Kediri District with the number 134, a sample of 120 respondents. The independent variables is Knowledge about gaining weight infants, the dependent variable incidence of stunting, the next were analyzed by chi-square statistic. The results showed most mothers children aged 0-24 mounth have a good knowledge about infant weight gain as much as 66 respondents (55.0\%), almost all children aged 0-24 mounth are not experienced anything undernourishment as many as 96 respondents (80.0\%) of total 120 respondents. The results of data analysis showed there is a strong relationship between maternal knowledge about weight gain of children 0 24 mounth with the incidence of stunting in Kediri District. The better knowledge of mothers about infant weight gain, the better the mother's behavior in the nutritional needs of children under five nutritional status can be improved.
\end{abstract}

Keywords :Increase Weight; Knowledge; Less Nutrition; Toddler

\begin{abstract}
ABSTRAK
Asupan gizi yang salah atau tidak sesuai dengan kebutuhan akan menimbulkan masalah malnutrisi dalam bentuk asupan berlebih ataupun berkurang. Adapun faktor yang mempengaruhi kurangnya asupan gizi pada balita yaitu karena kurangnya pengetahuan ibu. Tujuan penelitian untuk mengetahui hubungan pengetahuan ibu tentang kenaikan berat badan balita usia 0-24 bulan dengan kejadian balita gizi kurang di di Kota kediri. Desain penelitian analitik korelasional dengan pendekatan cross sectional. Responden diambil dengan teknik purposive sampling. Populasi semua ibu balita usia 0-24 bulan di Kota Kediri dengan jumlah 134 orang, sampel 120 responden. Variabel independen pengetahuan tentang kenaikan berat badan balita, variabel dependen kejadian balita gizi kurang, kemudian dianalisis dengan uji statistik chi-square. Hasil penelitian menunjukan sebagian besar ibu balita usia 024 bulan memiliki pengetahuan baik tentang kenaikan berat badan balita sebanyak sebanyak
\end{abstract}


66 responden $(55,0 \%)$, hampir seluruh balita usia 0-24 bulan tidak mengalami kejadian gizi kurang yaitu sebanyak 96 responden $(80,0 \%)$ dari total 120 responden. Hasil analisa data menunjukan bahwa terdapat hubungan yang kuat antara pengetahuan ibu tentang kenaikan berat badan balita usia 0-24 bulan dengan kejadian balita gizi kurang di Di Kota Kediri. Semakin baik pengetahuan yang dimiliki ibu tentang kenaikan berat badan balita maka semakin baik perilaku ibu dalam memenuhi kebutuhan nutrisi balita sehingga status gizi balita dapat meningkat.

Kata kunci : balita; gizi kurang; kenaikan berat badan; pengetahuan

\section{PENDAHULUAN}

Masalah gizi di Indonesia pada hakekatnya adalah masalah kesehatan masyarakat yang disebabkan oleh berbagai faktor yang saling terkait satu dengan lainnya (Supariasa, 2012). Peran orang tua sangat penting dalam pemenuhan gizi karena anak sangat membutuhkan perhatian dan dukungan orang tua dalam menghadapi pertumbuhan dan perkembangan yang sangat pesat (nurwijayanti, 2016). Menurut Sulystioningsih (2012) asupan gizi yang salah atau tidak sesuai dengan kebutuhan akan menimbulkan masalah malnutrisi dalam bentuk asupan berlebih ataupun berkurang. Adanya pengaruh lingkungan turut menentukan perkembangan anak. Interaksi dengan teman sebaya, pola asuh yang diterapkan oramg tua dan status ekonomi orang tua, karena berdampak pada kebiasaan makan anak. Kebiasaan makan balita yang buruk berakibat pada buruknya kondisi balita. Penurunan berat badan akan mengiringi memburuknya kondisi anak. Jika konsumsi buruk balita ini tidak mendapatkan perhatian orang tua,maka berdampak pada penurunan status gizi balita. Faktor gizi, kesehatan gigi, penyakit, permasalahan tidur anak serta perawatan orang tua saat anak sakit menjadi faktor yang mempengaruhi status gizi anak (Wong, 2009).

Data Riset Kesehatan Dasar tahun 2015 menunjukkan bahwa prevalensi balita dengan permasalahan gizi adalah 19,6\%, dengan distribusi sebesar 5,7\% untuk prevalensi balita gizi buruk dan 13,9\% untuk prevalensi balita gizi kurang. Berdasarkan prevalensi permasalahan gizi tersebut, maka kejadian gizi kurang di Indonesia termasuk sebagai permasalahan gizi karena prevalensinya hanya sedikit dibawah prevalensi yang ditetapkan WHO yang hanya sebesar 20\% (Kemenkes 2015). Prevalensi permasalahan gizi di Provinsi Jawa Timur pada tahun 2015 sebesar 19,1\%, hanya 
selisih 0,5\% dibandingkan dengan angka prevalensi gizi kurang nasional (Dinkes Jatim, 2016).

Sedangkan data permasalahan gizi di Kota Kediri pada tahun 2016 diketahui jumlah balita dengan status berat badan kurang sebanyak 522 balita atau sekitar $3,7 \%$ balita mengalami gizi kurang. Jumlah balita yang mempunyai berat badan kurang di Kota Kediri tersebut melebihi ambang batas Normal yakni kurang dari $1 \%$ dalam suatu wilayah (Dinkes Kota Kediri, 2016). Data dari Puskesmas Kota Wilayah Utara Kota Kediri pada tahun 2016 terdapat 1.647 balita dan 60 diantaranya $(3,8 \%)$ mengalami gizi kurang mengalami gizi buruk.

Hasil studi pendahuluan yang dilakukan pada tanggal 11 Juni 2017 di Di Kota kediri diketahui didapatkan data permasalahan gizi kurang pada balita dengan jumlah 20 balita. Hasil wawancara secara informal terhadap 10 orang tua balita dengan gizi kurang diketahui bahwa 6 orang tua memandang status gizi balita dilihat dari gemuk atau tidaknya anak, sedangkan untuk ukuran yang pasti seorang ibu belum dapat memahami sepenuhnya. Sedangkan 4 ibu lainnya mengatakan bahwa informasi yang diterima ketika Posyandu, kebanyakan ibu hanya mendapatkan informasi secara sekilas tentang berat badan anak serta dan cara untuk meningkatkannya jika berat badan anak kurang, namun jika berat badan anak normal atau lebih seringkali ibu tidak mendapatkan informasi yang berarti sehingga ibu kurang mengetahui berapakah kenaikan berat badan ideal bagi balita.

Tingkat pengetahuan orang tua tentang gizi sangat berpengaruh terhadap perilaku dan sikap dalam memilih makanan untuk anaknya. Keadaan gizi yang baik akan menentukan tingginya angka presentase status gizi secara nasional. Ketidaktahuan tentang makanan yang mempunyai gizi baik akan menyebabkan pemilihan makanan yang salah dan rendahnya gizi yang tekandung dalam makanan tersebut dan akan menyebabkan status gizi anak tersebut menjadi buruk dan kurang (Maulana, 2012).Tujuan penelitan ini adalah untuk mengetahui hubungan pengetahuan ibu tentang kenaikan berat badan balita usia 1-2 tahun dengan kejadian balita gizi kurangdi di Kota kediri. 


\section{METODE PENELITIAN}

Desain penelitian analitik korelasional dengan pendekatan cross sectional. Responden diambil dengan teknik purposive sampling. Populasi semua ibu balita usia0-24 bulandi kota Kediri dengan jumlah 134 orang, sampel 120 responden. Variabel independen dalam penelitian ini adalahpengetahuan tentang kenaikan berat badan balita, sedangkan variabel dependenadalah kejadian balita gizi kurang. Analisa data uji statistik chi-square.

Berdasarkan Tabel 1 diketahui bahwa dari total 120 responden yang berusia 20-35 tahun yaitu sebanyak40 responden (33.3\%), berpendidikan SMA yaitu sebanyak 51 responden (42,5\%), bekerja sebagai wiraswasta yaitu sebanyak 13 responden $(10,83 \%), \quad$ memiliki pendapatan 1.600.000-2.600.000 yaitu sebanyak 47 responden (39,16\%), memberikan makanan $3 \mathrm{x} /$ hari yaitu sebanyak 112 responden (93,3\%), memiliki pengetahuan cukup tentang kenaikan berat badan balita yaitu sebanyak 62 responden $(51,6 \%)$ dan tidak mengalami kejadian gizi kurang yaitu sebanyak 96 responden $(80 \%)$.

\section{HASIL}

Tabel 1. Karakteristik Responden

\begin{tabular}{lcc}
\hline Karakteristik & $\sum \mathrm{N}$ & $\Sigma \%$ \\
\hline Usia & & \\
$<20$ & 34 & 28,3 \\
$20-35$ & 40 & 33,3 \\
$>35$ & 46 & 38,3 \\
\hline Pendidikan & & \\
SD & 22 & 1,83 \\
SMA & 51 & 42,5 \\
Sarjana & 47 & 39,16 \\
\hline Pekerjaan & & \\
Tidak bekerja & 12 & 10 \\
Swasta & 69 & 57,5 \\
Wiraswasta & 13 & 10.83 \\
PNS & 26 & 21.66 \\
\hline Pendapatan per bulan & \\
$<1.600 .000$ & 14 & 11,6 \\
1.600.000- & 47 & 39,16 \\
2.600.000 & 59 & 49,16 \\
$>2.600 .000$ & & \\
\hline Pemberian makan $3 \times$ sehari \\
Ya & 112 & 93,3 \\
Tidak & 8 & 6,66 \\
\hline Pengetahuan & & \\
Kurang & 29 & 24,16 \\
Cukup & 62 & 51,66 \\
Baik & 31 & 25,83 \\
\hline Kejadian gizi kurang & \\
Ya & 24 & 20 \\
Tidak & 96 & 80 \\
\hline Total & 120 & 100 \\
\hline & & \\
\hline
\end{tabular}

Tabel 2. Hasil Analisa Data

\begin{tabular}{lcc}
\hline Variabel & $\begin{array}{c}\text { Asymp. } \\
\text { Sig. (2- } \\
\text { sided) }\end{array}$ & $\begin{array}{c}\text { Contingency } \\
\text { Coefficient }\end{array}$ \\
\hline $\begin{array}{l}\text { Pengetahuan } \\
\text { dengan }\end{array}$ & & \\
$\begin{array}{l}\text { kejadian balita } \\
\text { gizi kurang di }\end{array}$ & .000 & .652 \\
Di Kota kediri & & \\
\hline
\end{tabular}

Berdasarkan hasil uji statistik chi-square yang telah dilakukan diketahui bahwa 
nilai pvalue $=0,000<\alpha 0,05$ dengan nilai Contingency Coefficient 0,652 sehingga H1 diterima yang artinya terdapat hubungan yang kuat antara pengetahuan ibu tentang kenaikan berat badan balita usia 0-24 bulan dengan kejadian balita gizi kurang di Di Kota kediri.

\section{PEMBAHASAN}

\section{Pengetahuan Ibu Tentang Kenaikan}

Berat Badan Balita Usia 0-24 bulanDi

\section{Kota kediri.}

Sebagian besar ibu balita usia 0-24 bulandi di Kota kediri memiliki pengetahuan baik tentang kenaikan berat badan balita. Pengetahuan merupakan hasil tahu dan ini terjadi setelah orang melakukan penginderaan terhadap suatu obyek tertentu (Notoatmojo, 2010). Penginderaan terjadi melalui panca indera manusia, yakni indera penglihatan,pendengaran, penciuman, rasa dan raba. Sebagian besar pengetahuan manusia diperoleh melalui mata dan telinga. Sedangkan yang dimaksud dengan status gizi yaitu suatu ukuran mengenai kondisi tubuh seseorang yang dapat dilihat dari makanan yang dikonsumsi dan penggunaan zat-zat gizi di dalam tubuh. Status gizi dibagi menjadi tiga kategori, yaitu status gizi kurang, gizi normal, dan gizi lebih (Almatsier, 2010). Status gizi normal merupakan suatu ukuran status gizi dimana terdapat keseimbangan antara jumlah energi yang masuk ke dalam tubuh dan energi yang dikeluarkan dari luar tubuh sesuai dengan kebutuhan individu. Energi yang masuk ke dalam tubuh dapat berasal dari karbohidrat, protein, lemak dan zat gizi lainnya $(\mathrm{Nix}$, 2015).

Adapun faktor-faktor yang mempengaruhi pengetahuan ibu tentang kenaikan berat badan balita yaitu faktor internal seperti umur, sikap, kehendak/kemauan, dan faktor eksternal seperti pendidikan, informasi, pengalaman, pelatihan, lingkungan, palayanan kesehatan dan petugas kesehatan (Notoatmojo, 2010).Sebagian besar ibu balita memiliki pengetahuan yang baik mengenai peningkatan berat badan balita, hal ini menunjukan bahwa ibu balita di Kelurahan Setono Pande memiliki pengetahuan yang memadai akan kenaikan berat badan, pertumbuhan, perkembangan dan pemenuhan gizi anak. Banyaknya ibu balita yang berpengetahuan baik merupakan suatu hal yang positif, kerena dengan tingginya pengetahuan yang dimiliki oleh ibu akan berdampak pada pertumbuhan dan 
perkembangan anak mereka, karena ibu yang memiliki pengetahuan baik akan mengetahui proses tumbuh kembang anaknya serta kebutuhan akan zat gizi yang dibutuhkan anak dalam proses tumbuh kembang tersebut, dimana orang tua akan menyajikan dan memberikan makanan yang bergizi untuk anak, memperhatikan kebersihan makanan yang dikonsumsi anak serta melakukan pemantauan pertumbuhan dan perkembangan anak di tempat pelayanan kesehatan.

Hasil penelitian juga menunjukan bahwa masih terdapat beberapa ibu dengan pengetahuan cukup dan kurang, hal ini akan berdampak negatif pada perumbuhan, perkembangan anak dan pemenuhan gizi anak, karena pada ibu yang kurang memiliki pengetahuan akan kurang memperhatikan kebutuhan akan pemenuhan nutiri pada anak, serta jarang melakukan pemantaun pertumbuhan dan perkembangan anak, karena ibu tidak mengetahui apa yang harus ibu lakukan dalam memenuhi kebutuhan nutrisi anak.

\section{Kejadian Balita Gizi Kurang Di Kota kediri}

Hampir seluruh balita usia 0-24 bulandi di Kota kediri tidak mengalami kejadian gizi kurang .Masa balita merupakan masa yang menentukan dalam tumbuh kembangnya yang akan menjadikan dasar terbentuknya manusia seutuhnya. Karena itu pemerintah memandang perlu untuk memberikan suatu bentuk pelayanan yang menunjang tumbuh kembang balita secara menyeluruh terutama dalam aspek mental dan sosial. Pertumbuhan dan perkembangan saling mendukung satu sama lain perkembangan seorang anak tidak dapat maksimal tanpa dukungan atau optimalnya pertumbuhan. Misalnya seorang anak yang kekurangan gizi akan mempengaruhi perkembangan mental maupun sosialnya, oleh karena itu keduanya harus mendapat perhatian baik dari pemerintah, masyarakat maupun orang tua (Supariasa, 2012).

Menurut Arisman (2010) status gizi merupakan keadaan kesehatan sebagai akibat keseimbangan antara konsumsi, penyerapan zat gizi dan penggunaannya didalam tubuh. Dalam menentukan status gizi balita harus ada ukuran baku yang sering disebut reference. Pengukuran baku antropomentri yang sekarang digunakan di Indonesia adalah WHO-NCHS. Menurut Harvard dalam Supariasa (2012), klasifikasi status gizi dapat dibedakan menjadi empat yaitu gizi lebih, gizi baik, gizi kurang dan yang terakhir yaitu gizi 
buruk. Menurut Supariasa (2012) faktorfaktor yang dapat mempengaruhi status gizi balita yaitu keadaan infeksi, tingkat konsumsi makanan, pengaruh budaya, penyediaan pangan, keterjangkauan pelayanan kesehatan, higiene dan sanitasi lingkungan, jumlah anggota dalam keluarga, tingkat pengetahuan dan pendidikan ibu.

Hasil penelitian menunjukan bahwa hampir seluruh balita usia 1-2 tahun di Kelurahan Setono Pande tidak mengalami kejadian gizi kurang, hal ini menunjukan bahwa status gizi seluruh balita usia 1-2 tahun di Kelurahan Setono Pande sangat bagus karena mencapai angka $80 \%$, tingginya angka status gizi baik di Kelurahan Setono Pande tidak terlepas dari kemampaun orang tua dalam memberikan nutrisi yang cukup yang dibutuhkan oleh balita baik dari segi pengetahuan tentang cara pemenuhan gizi balita maupun finansial untuk memenuhi kebutuhan nutrisi anak.

Hasil penelitian juga menunjukan bahwa sebagian kecil balita mempunyai gizi kurang, hal ini disebabkan karena kurangnya pengetahuan orang tua dalam menyiapkan bahan makanan yang dibutuhkan balita dan kurangnya kemampuan orang tua dalam memenuhi kebutuhan nutrisi anak, serta pada beberapa anak ada yang mengalami penyakit infeksi.Hal ini dibuktikan berdasarkan hasil wawancara yang dilakukan peneliti dengan orang tua yang anaknya gizi kurang mereka mengatakan bahwa tidak mengetahui kebutuhan gizi yang diperlukan anak dan dalam kehidupan sehari-hari anak hanya mengkonsumsi makanan seadanya saja seperti nasi dan sayur saja, dan jarang mengkonsumsi telur dan daging, hal ini menunjukan bahwa balita kurang mengkonsumsi makanan yang bergizi yang dibutuhkan oleh balita untuk pertumbuhan dan perkembangan selanjutnya. Pada balita dengan gizi kurang apabila tidak segera ditangani akan menyebabkan terganggunya pertumbuhan dan perkembangan anak.

\section{Hubungan Pengetahuan Ibu Dengan Kejadian Balita Gizi Kurang}

Berdasarkan hasil uji statistik chi-square yang telah dilakukan diketahui bahwa nilai pralue $=0,000<\alpha 0,05$ dengan nilai Contingency Coefficient 0,652 sehingga H1 diterima yang artinya terdapat hubungan yang kuat antara pengetahuan ibu tentang kenaikan berat badan balita usia 0-24 bulandengan kejadian balita gizi kurang di 
Di Kota kediri. Tabulasi pengetahuan ibu tentang kenaikan berat badan balita usia 0-24 bulan dengan kejadian balita gizi kurang menunjukan bahwa sebagian besar ibu balita yang memiliki pengetahuan tentang kenaikan berat badan balita usia 0-24 bulandengan kategori baik di di Kota kediri memiliki anak yang tidak mengalami kejadian gizi kurang yaitu sebanyak 96 responden $(80 \%)$ dari total 40 responden.

Menurut Mubarak (2012), pengetahuan seseorang akan menjadi dasar bagi seseorang untuk bersikap dan pada akhirnya akan mempengaruhi perilakunya. Pengetahuan tentang status gizi akan mempengaruhi kebiasaan makan atau perilaku makan suatu masyarakat (Emilia, E., 2008). Apabila penerimaan perilaku baru didasari oleh pengetahuan, kesadaran dan sikap yang positif maka perilaku tersebut dapat berlangsung lama (long lasting). Sebaliknya apabila perilaku itu tidak disadari oleh pengetahuan dan kesadaran tidak akan berlangsung lama. Seperti halnya juga pada ibu balita apabila mempunyai pengetahuan yang baik tentang status gizi diharapkan dapat menjaga balita dan anggota keluarganya mempunyai status gizi yang baik pula (Notoatmodjo, 2007).
Berdasarkan uraian fakta dan teori di atas peneliti berpendapat bahwa ada hubungan antara pengetahuan ibu tentang kenaikan berat badan balita dengan kadian gizi kurang pada balita usia 1-2 tahun di kelurahan Setono Pande. Hal ini menunjukan bahwa pengetahuan ibu akan pertumbuhan, perkembangan dan kebutuhan nutrisi balita sangat penting untuk pertumbuhan dan perkembangan anak. Dimana pada ibu dengan pengetahuan baik akan menyiapkan dan memberikan makanan dengan gizi yang baik pada anaknya sehingga anak dapat bertumbuh dan berkembang sesuai dengan tahapannya, sedangkan pada ibu dengan pengetahuan kurang, tidak mengetahui apa yang harus ibu lakukan untuk memenuhi kebutuhan nutrisi anak dalam menunjang pertumbuan dan perkembangan anak, hal ini akan berdampak pada status gizi anak sehingga menyebabkan anak mengalami gizi kurang. Keadaan status gizi kurang akan membawa dampak yang luas diantaranya mudahnya anak mengalami infeksi serta gangguan tumbuh kembang dan gangguan fungsi organ tubuhnya.

\section{KESIMPULAN}

1. Sebagian besar ibu balita usia 0-24 bulan di di Kota kediri memiliki 
pengetahuan cukup tentang kenaikan berat badan balita

2. Hampir seluruh balita usia 0-24 bulan di di Kota kediri tidak mengalami kejadian gizi kurang

3. Ada hubungan antara pengetahuan ibu tentang kenaikan berat badan balita usia0-24 bulandengan kejadian balita gizi kurang di Di Kota kediri.

Direkomendasikan bagi peneliti selanjutnya agar dapat melakukan penelitian lanjutan dengan mengkaji faktor lain yang dapat mempengaruhi kejadian gizi buruk pada balita seperti faktor pemberian makanan tambahan pada balita usia0-24 bulan.

\section{REFERENSI}

Almatsier. (2010). Prinsip Dasar Gizi. Jakarta: Gramedia Pustaka Utama

Arisman. (2010). Gizi Dalam Daur Kehidupan. Jakarta:Penerbit Buku Kedokteran EGC

Dinkes Jatim. (2016). Profil Kesehatan Provinsi Jawa Timur Tabun 2016. Surabaya: Dinas Kesehatan.

Emilia, E.(2008). Pengembangan Alat Ukur Pengetahuan, Sikap dan Praktek pada Gizi Remaja. Diakses 23 Mei 2012. http:/ / repository.ipb.ac.id/
Kemenkes RI. (2015). Profil Kesehatan Indonesia 2015. Jakarta: Kementerian Kesehatan RI.

Mubarak, W.I. (2012). PromosiKesehatan :Sebuah Pengantar Proses Belajar Mengajar Dalam Pendidikan. Yogyakarta : Graha Ilmu

Nix. (2015). William's Basic Nutrition \& Diet Therapy, Twelfth Edition. Elsevier Mosby Inc, USA

Notoatmodjo, S. (2007). Ilmu Perilaku Kesehatan. Jakarta : PT Rineka Cipta

Notoatmodjo, S. (2010). Metode Penelitian Kesehatan. Jakarta : P.T. Rineka Cipta

Nurwijayanti,(2016). Keterkaitan Kekurangan Energi Protein (KEP) dengan Kejadian Infeksi Saluran Pernafasan Akut (ISPA) Pada Balita Usia (1-5 tahun). Malang: Jurnal Care Vol. 4, No.3

Sulistyoningsih. (2011). Gizi Untuk Kesehatan Ibu dan Anak. Yogyakarta: Graha Ilmu.

Supariasa. (2012). Penilaian Status Giz̨i. Jakarta: EGC.

Wong, D, dkk. (2009). Buku Ajar Keperawatan Pediatrik. Volume 1. Penerbit Buku Kedokteran EGC : Jakarta 